\title{
The Potential Beneficial Effect of EPA and DHA Supplementation Managing Cytokine Storm in Coronavirus Disease
}

\author{
Zoltán Szabó ${ }^{*}$, Tamás Marosvölgyi ${ }^{2}$, Éva Szabó ${ }^{3}$, Péter Bai ${ }^{4,5,6}$, Mária Figler $^{1,7}$ and \\ Zsófia Verzár ${ }^{1}$ \\ ${ }^{1}$ Faculty of Health Sciences, Institute of Nutritional Sciences and Dietetics, University of Pecs, Pecs, Hungary, ${ }^{2}$ Medical \\ School, Institute of Bioanalysis, University of Pecs, Pecs, Hungary, ${ }^{3}$ Department of Biochemistry and Medical Chemistry, \\ Medical School, University of Pecs, Pecs, Hungary, ${ }^{4}$ Department Medical Chemistry, Faculty of Medicine, University of \\ Debrecen, Debrecen, Hungary, ${ }^{5}$ MTA-DE Lendület Laboratory of Cellular Metabolism, Debrecen, Hungary, ${ }^{6}$ Faculty of \\ Medicine, Research Center for Molecular Medicine, University of Debrecen, Debrecen, Hungary, ${ }^{7}$ 2nd Department of Internal \\ Medicine and Nephrology Centre, Clinical Centre, University of Pecs, Pecs, Hungary
}

Keywords: COVID-19, DHA - 22:6n-3, EPA - 20:5n-3, supplementation, IL-6 (Interleukin 6), IL-1ß

\section{OPEN ACCESS}

Edited by:

Anna Maria Giudetti

University of Salento, Italy

Reviewed by:

Angelo Baldassare Cefalù,

University of Palermo, Italy

Gérard Lizard,

Université de Bourgogne, France

*Correspondence:

Zoltán Szabó

szabo.zoltan.diet@gmail.com

Specialty section

This article was submitted to Lipid and Fatty Acid Research, a section of the journal Frontiers in Physiology

Received: 27 April 2020 Accepted: 10 June 2020

Published: 19 June 2020

Citation:

Szabó Z, Marosvölgyi T, Szabó É,

Bai P, Figler M and Verzár Z (2020) The Potential Beneficial Effect of EPA and DHA Supplementation Managing

Cytokine Storm in Coronavirus Disease. Front. Physiol. 11:752. doi: 10.3389/fphys.2020.00752
In the recent COVID-19 (caused by SARS-Cov-2 virus) pandemic a subgroup of patient death is attributed to the so-called "cytokine storm" phenomenon (also called cytokine release syndrome or macrophage overactivation syndrome) (Mehta et al., 2020). To date, the molecular events that precipitate a "cytokine storm" or the applicable therapeutic strategies to prevent and manage this process is not elucidated because of the complex nature of this problem (Tisoncik et al., 2012). Recent articles suggest that specific nutrients such as vitamin $\mathrm{B}_{6}, \mathrm{~B}_{12}, \mathrm{C}, \mathrm{D}, \mathrm{E}$, and folate; trace elements, including zinc, iron, selenium, magnesium, and copper may play a key role in the management of cytokine storm (Calder et al., 2020; Grant et al., 2020; Muscogiuri et al., 2020). Among these micronutrients LC-PUFAs (long chain polyunsaturated fatty acids) such as EPA (eicosapentaenoic acid) and DHA (docosahexaenoic acid) are noteworthy because of their direct influence in the immunological response to viral infections (Calder et al., 2020; Messina et al., 2020).

In this paper, we would like to draw the attention to the possible beneficial effect of EPA and DHA supplementation in SARS-CoV-2 infection and urge the medical community for further investigations and conduction of clinical trials.

Evidence suggests that n-3 LC-PUFAs can modulate the immune response and function in many ways (Calder, 2007, 2013; Zivkovic et al., 2011; Maskrey et al., 2013; Tao, 2015; AllamNdoul et al., 2017). Among these complex immunomodulatory effects, interleukin-6 (IL-6) and interleukin-1ß (IL-1 $\beta$ ) - because of the suspected central regulatory role in the "cytokine storm" should be highlighted. These cytokines can be affected by dietary EPA and DHA intake (Figure 1). In addition, poly(ADP-ribose) polymerase enzymes that have anti-inflammatory properties, translatable to human COVID-19 infection were shown to improve tissue levels of DHA and EPA, as well as the downstream anti-inflammatory metabolites of EPA and DHA (Kiss et al., 2015; Curtin et al., 2020) further underscoring the applicability of DHA and EPA in COVID-19.

IL-6 blockade using Tocilizumab monoclonal antibody has been identified as a feasible therapeutic target in SARS-CoV-infections (Liu et al., 2020), nevertheless, reducing the expression of additional proinflammatory cytokines (e.g., IL-1ß, IL-38) may have beneficial effects (Conti et al., 2020). 


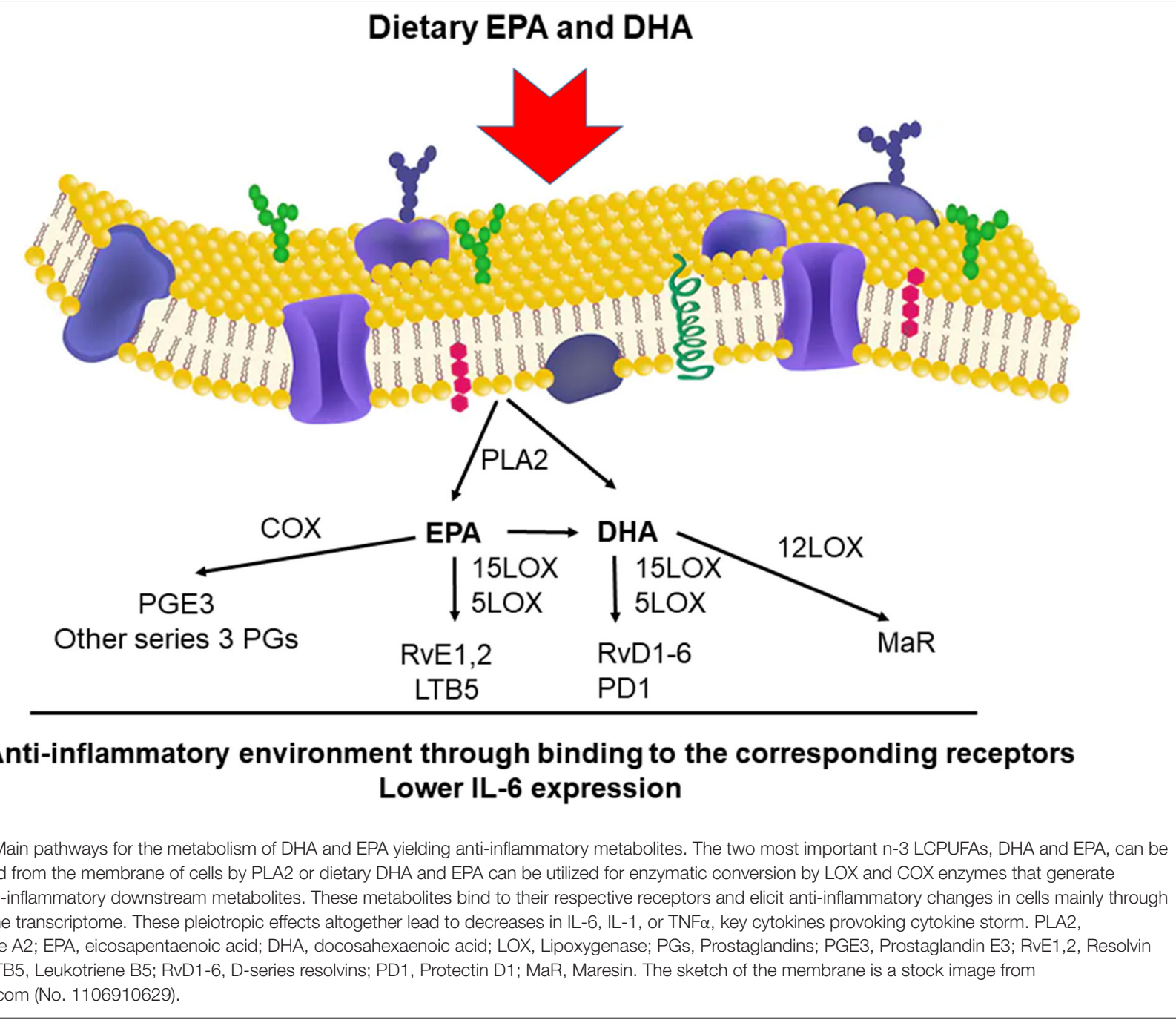

Both EPA and DHA can decrease the secretion of inflammatory cytokines in vitro and animal studies (Gutierrez et al., 2019). Pre-supplementation with DHA (400 mM) significantly decreased the release of IL- 6 and IP- 10 by Calu- 3 cells infected with Rhinovirus RV-43 and RV-1B (Saedisomeolia et al., 2009).

Based on the results of a randomized, controlled study published in 2018, high-dose (1.5 g/day EPA and $1.0 \mathrm{~g} /$ day DHA) n-3 supplementation can reduce plasma levels of both IL-6 and IL-1ß (Tan et al., 2018). The anti-inflammatory effect of EPA and DHA supplementation seems consistent with most of the previous clinical findings (Fritsche, 2006; Vedin et al., 2008; Kiecolt-Glaser et al., 2012; Muldoon et al., 2016; Calder et al., 2020) (Table 1).

A DHA metabolite (17-hDHA) can reduce IL-6 secretion in human B cells (Ramon et al., 2012).

The triglyceride-lowering effect of n-3 LC-PUFA supplementation is well-known (Yanai et al., 2018; Zhou et al., 2019; Abdelhamid et al., 2020). Lower levels of triglyceride present a lower risk of developing a "cytokine storm" based on the score from the available sHLH score system (Mehta et al., 2020). This approach represents another standpoint for the promotion of n-3 LC-PUFA supplementation in COVID-19 disease.

In addition, evidence suggests that in non-viral infected critically ill patients n-3 LC-PUFA supplementation can be helpful but data are highly limited (Rangel-Huerta et al., 2012). A recent meta-analysis reported the effects of omega-3 fatty acids and/or antioxidants in adults with acute respiratory distress syndrome in which the authors concluded that any beneficial effect in the duration of ventilator days and ICU length of stay or oxygenation at day 4 seems uncertain because of the very low quality of evidence (Dushianthan et al., 2019). To date there is no direct evidence of any beneficial or deleterious effect of immunonutrition with EPA and DHA in COVID-19 patients.

EPA and DHA supplementation can alter many biological pathways which may have direct influence in the outcome of COVID-19 (Fenton et al., 2013; Duvall and Levy, 2016; Curtin et al., 2020). 
TABLE 1 | The effects of DHA and EPA supplementation on cytokine production.

\begin{tabular}{|c|c|c|c|c|}
\hline References & Type & Supplementation & Subjects & Effects \\
\hline Ramon et al. (2012) & in vitro & $\begin{array}{l}\text { a50 nM 17-hDHA } \\
\text { b100 nM 17-hDHA }\end{array}$ & CD19+ $\mathrm{B}$ cells & $\begin{array}{l}\text { IL- } 6 \downarrow 44 \% \%^{\mathrm{a}} \\
\text { IL-10 } \downarrow 49 \% \text { a; } 54 \%{ }^{\mathrm{b}} \\
\text { TNF- } \alpha\end{array}$ \\
\hline Allam-Ndoul et al. (2017) & in vitro & $\begin{array}{l}{ }^{\mathrm{a}} 10 \mu \mathrm{M} \text { DHA } \\
{ }^{\mathrm{b}} 50 \mu \mathrm{M} \text { DHA } \\
{ }^{\mathrm{c}} 75 \mu \mathrm{M} \text { DHA } \\
{ }^{\mathrm{d}} 10 \mu \mathrm{M} \text { EPA } \\
{ }^{\mathrm{e}} 50 \mu \mathrm{M} \text { EPA } \\
{ }^{\mathrm{f}} 75 \mu \mathrm{M} \text { EPA }\end{array}$ & $\begin{array}{l}\text { THP-1 acute monocytic leukemia cell } \\
\text { line }\end{array}$ & $\begin{array}{l}\text { IL-6 } \downarrow 12 \%^{\mathrm{a}} ; 19 \%^{\mathrm{b}} ; 30 \%^{\mathrm{c}} ; 6 \%^{\mathrm{d}} ; \\
13 \%^{\mathrm{e}} ; 24 \%^{\mathrm{f}} \\
\text { TNF } \downarrow 6 \%^{\mathrm{a}} ; 12 \%^{\mathrm{b}} ; 15 \%^{\mathrm{c}} ; 18 \%^{\mathrm{f}}\end{array}$ \\
\hline \multirow[t]{2}{*}{ Saedisomeolia et al. (2009) } & in vitro & $\begin{array}{l}{ }^{\mathrm{a}} 200 \mu \mathrm{M} \text { DHA } \\
{ }^{\mathrm{b}} 400 \mu \mathrm{M} \text { DHA } \\
{ }^{\mathrm{c}} 200 \mu \mathrm{M} \text { EPA }\end{array}$ & $\begin{array}{l}\text { Airway epithelial cells (Calu-3) with } \\
\text { RV-43 }\end{array}$ & $\begin{array}{l}\text { IL-6 } \downarrow 16 \% \mathrm{~b} \\
\text { IL-8 } \\
\text { IP-10 } \downarrow 28 \% \text { b }\end{array}$ \\
\hline & & ${ }^{d} 400 \mu \mathrm{M}$ EPA & $\begin{array}{l}\text { Airway epithelial cells (Calu-3) with } \\
\text { RV-1B }\end{array}$ & $\begin{array}{l}\text { IL- } 6 \downarrow 13 \%^{\mathrm{a}} ; 29 \%^{\mathrm{b}} \\
\text { IL-8 } \\
\mathrm{IP}-10 \downarrow 24 \% \mathrm{~b}\end{array}$ \\
\hline Tan et al. (2018) & $\mathrm{RCT}$ & $\begin{array}{l}{ }^{\mathrm{a}} 1.5 \mathrm{~g} / \text { day DHA 4th weeks } \\
\text { b1.5 g/day DHA 8th weeks }\end{array}$ & $\begin{array}{l}\text { Plasma of patients with chronic } \\
\text { venous leg ulcers }\end{array}$ & $\begin{array}{l}\text { IL- } 6 \downarrow 12 \%^{\mathrm{a}} ; 22 \%^{\mathrm{b}} \\
\text { IL-1ß } \downarrow 29 \%^{\mathrm{a}} ; 44 \%^{\mathrm{b}} \\
\text { TNF- } \alpha \downarrow 12 \%^{\mathrm{a}} ; 23 \%^{\mathrm{b}}\end{array}$ \\
\hline Vedin et al. (2008) & $\mathrm{RCT}$ & $\begin{array}{l}1.7 \mathrm{~g} / \text { day } \mathrm{DHA} \\
\text { and } \\
0.6 \mathrm{~g} / \text { day EPA }\end{array}$ & $\begin{array}{l}\text { Blood mononuclear leukocytes of } \\
\text { Alzheimer disease patients }\end{array}$ & $\begin{array}{l}\text { IL- } 6 \downarrow 43 \% \\
\text { IL-1ß } \downarrow-35 \% \\
\text { TNF- } \alpha\end{array}$ \\
\hline Kiecolt-Glaser et al. (2012) & $\mathrm{RCT}$ & $\begin{array}{l}\text { a } 2.5 \mathrm{~g} / \text { day n-3 PUFAs } \\
\mathrm{b}_{1} .25 \mathrm{~g} / \text { day } \mathrm{n}-3 \text { PUFAs }\end{array}$ & Serum of healthy adults & $\begin{array}{l}\mathrm{IL}-6 \downarrow^{\mathrm{a}, \mathrm{b}} \\
\mathrm{TNF}-\alpha \downarrow^{\mathrm{a}, \mathrm{b}}\end{array}$ \\
\hline Zhou et al. (2019) & $\mathrm{RCT}$ & $\begin{array}{l}{ }^{a} 3.6 \mathrm{~g} / \text { day EPA + DHA } \\
\mathrm{b}_{1} .8 \mathrm{~g} / \text { day EPA + DHA }\end{array}$ & $\begin{array}{l}\text { Peripheral blood mononuclear cells } \\
\text { (PBMCs) in Hypercholesterol-emic } \\
\text { Adults }\end{array}$ & $\begin{array}{l}\text { TG } \downarrow 20 \%^{\mathrm{a} ;} 13 \%{ }^{\mathrm{b}} \\
\text { IL-6 } \downarrow 37 \%^{\mathrm{a} ;} \\
\text { TNF }-\alpha\end{array}$ \\
\hline Muldoon et al. (2016) & $\mathrm{RCT}$ & $\begin{array}{l}0.4 \mathrm{~g} / \text { day } \mathrm{DHA} \\
\text { and } \\
1.0 \mathrm{~g} / \text { day EPA }\end{array}$ & Serum of healthy adults & IL-6 \\
\hline
\end{tabular}

$\%$ change in the expression of cytokines upon DHA and/or EPA supplementation were either calculated from original data or reproduced from given publications, where available. $A \downarrow$ notation stands for a statistically significant decrease in the measured levels of the examined cytokines. Identical superscripts both in the "Supplementation" and "Effects" columns (a, $b, c, d, e, f)$ denote the published effect(s) of the given supplementation group/dose.

The safety of EPA and DHA supplementation should be also highlighted. Although, the US Department of Health \& Human Services National Institutes of Health Office of Dietary Supplements (ODS) concluded that a daily intake of EPA+DHA of up to $3.0 \mathrm{~g} / \mathrm{d}$ is safe (Usdhhs N. I. O. H. and Office of Dietary Supplements, 2019), the European Food Safety Authority (EFSA) stated that the long-term consumption of EPA and DHA supplements at combined doses of up to about $5 \mathrm{~g} /$ day appears to be safe for the general public (EFSA, 2012). In addition some evidence suggest that longterm supplementation of EPA and DHA may have side effects such as increasing risk of certain types of cancers, but the results are conflicting (Gerber, 2012; Alexander, 2013; Serini and Calviello, 2018). It should be also noticed that the usage of algae- or plant-based sources of EPA and DHA seems more preferable than marine or animal-based sources (Doughman et al., 2007; Lane et al., 2014; Harwood, 2019).

Summary: Based on the available data, the supplementation of EPA and DHA in COVID-19 patients appears to have potential beneficial effect in managing the "cytokine storm." Therefore, the use of EPA and DHA supplementation should be considered as both a supportive therapy and a prevention strategy in SARS-Cov-2 infection.

\section{AUTHOR CONTRIBUTIONS}

ZS, TM, and ÉS drafted the manuscript. TM, PB, and ZS designed the figure and the table. MF, ZV, and ÉS substantial contributions to the conception by supervising all the processes. $\mathrm{PB}, \mathrm{MF}, \mathrm{ZV}$, and ÉS revised the manuscript critically for important intellectual content. TM and ZS drafted the reference list. ZS and TM proofread the final manuscript. All authors agree that our work is accountable for all aspects of the work in ensuring that questions related to the accuracy or integrity of any part of the work are appropriately investigated and resolved. All authors read and approved the final manuscript.

\section{ACKNOWLEDGMENTS}

TM and ÉS was supported by grants from NKFIH K120193. PB work was supported by grants from NKFIH (K123975, GINOP-2.3.2-15-2016-00006), the Momentum fellowship of the Hungarian Academy of Sciences and the University of Debrecen. The research was financed by the Higher Education Institutional Excellence Programme (NKFIH-1150-6/2019) of the Ministry of Innovation and Technology in Hungary, within the framework of the Biotechnology thematic programme of the University of Debrecen. 


\section{REFERENCES}

Abdelhamid, A. S., Brown, T. J., Brainard, J. S., Biswas, P., Thorpe, G. C., Moore, H. J., et al. (2020). Omega-3 fatty acids for the primary and secondary prevention of cardiovascular disease. Cochrane Database Syst. Rev. 3:CD003177. doi: 10.1002/14651858.CD003177.pub5

Alexander, W. (2013). Prostate cancer risk and omega-3 Fatty Acid intake from fish oil: a closer look at media messages versus research findings. $P$ T 38, 561-564.

Allam-Ndoul, B., Guenard, F., Barbier, O., and Vohl, M. C. (2017). A study of the differential effects of eicosapentaenoic acid (EPA) and docosahexaenoic acid (DHA) on gene expression profiles of stimulated Thp-1 macrophages. Nutrients 9:424. doi: $10.3390 /$ nu9050424

Calder, P. C. (2007). Immunomodulation by omega-3 fatty acids. Prostaglandins Leukot. Essent. Fatty Acids 77, 327-335. doi: 10.1016/j.plefa.2007.10.015

Calder, P. C. (2013). n-3 fatty acids, inflammation and immunity: new mechanisms to explain old actions. Proc. Nutr. Soc. 72, 326-336. doi: $10.1017 /$ S0029665113001031

Calder, P. C., Carr, A. C., Gombart, A. F., and Eggersdorfer, M. (2020). Optimal nutritional status for a well-functioning immune system is an important factor to protect against viral infections. Nutrients 12:1181. doi: 10.3390/nu12041181

Conti, P., Ronconi, G., Caraffa, A., Gallenga, C. E., Ross, R., Frydas, I., et al. (2020). Induction of pro-inflammatory cytokines (IL-1 and IL-6) and lung inflammation by Coronavirus-19 (COVI-19 or SARSCoV-2): anti-inflammatory strategies. J. Biol. Regul. Homeost. Agents. doi: 10.23812/CONTI-E. [Epub ahead of print].

Curtin, N., Banyai, K., Thaventhiran, J., Le Quesne, J., Helyes, Z., and Bai, P. (2020). Repositioning PARP inhibitors for SARS-CoV-2 infection (COVID-19); a new multi-pronged therapy for ARDS? Br. J. Pharmacol. doi: 10.1111/bph.15137. [Epub ahead of print].

Doughman, S. D., Krupanidhi, S., and Sanjeevi, C. B. (2007). Omega-3 fatty acids for nutrition and medicine: considering microalgae oil as a vegetarian source of EPA and DHA. Curr. Diabetes Rev. 3, 198-203. doi: $10.2174 / 157339907781368968$

Dushianthan, A., Cusack, R., Burgess, V. A., Grocott, M. P., and Calder, P. C. (2019). Immunonutrition for acute respiratory distress syndrome (ARDS) in adults. Cochrane Database Syst. Rev. 1:CD012041. doi: 10.1002/14651858.CD012041.pub2

Duvall, M. G., and Levy, B. D. (2016). DHA- and EPA-derived resolvins, protectins, and maresins in airway inflammation. Eur. J. Pharmacol. 785, 144-155. doi: 10.1016/j.ejphar.2015.11.001

EFSA (2012). EFSA Panel on Dietetic Products, Nutrition and Allergies (NDA); Scientific Opinion Related to the Tolerable Upper Intake Level of Eicosapentaenoic acid (EPA), Docosahexaenoic Acid (DHA) and Docosapentaenoic Acid (DPA). P. European Food Safety Authority (Efsa), Italy. EFSA Journa).

Fenton, J. I., Hord, N. G., Ghosh, S., and Gurzell, E. A. (2013). Immunomodulation by dietary long chain omega-3 fatty acids and the potential for adverse health outcomes. Prostaglandins Leukot. Essent. Fatty Acids 89, 379-390. doi: 10.1016/j.plefa.2013.09.011

Fritsche, K. (2006). Fatty acids as modulators of the immune response. Annu. Rev. Nutr. 26, 45-73. doi: 10.1146/annurev.nutr.25.050304.092610

Gerber, M. (2012). Omega-3 fatty acids and cancers: a systematic update review of epidemiological studies. Br. J. Nutr. 107(Suppl. 2), S228-S239. doi: $10.1017 /$ S0007114512001614

Grant, W. B., Lahore, H., Mcdonnell, S. L., Baggerly, C. A., French, C. B., Aliano, J. L., et al. (2020). Evidence that vitamin D supplementation could reduce risk of influenza and COVID-19 infections and deaths. Nutrients 12, 988. doi: 10.3390/nu12040988

Gutierrez, S., Svahn, S. L., and Johansson, M. E. (2019). Effects of Omega-3 fatty acids on immune cells. Int. J. Mol. Sci. 20, 5028. doi: 10.3390/ijms20205028

Harwood, J. L. (2019). Algae: critical sources of very long-chain polyunsaturated fatty acids. Biomolecules 9, 708. doi: 10.3390/biom9110708

Kiecolt-Glaser, J. K., Belury, M. A., Andridge, R., Malarkey, W. B., Hwang, B. S., and Glaser, R. (2012). Omega-3 supplementation lowers inflammation in healthy middle-aged and older adults: a randomized controlled trial. Brain Behav. Immun. 26, 988-995. doi: 10.1016/j.bbi.2012.05.011

Kiss, B., Szanto, M., Szklenar, M., Brunyanszki, A., Marosvolgyi, T., Sarosi, E., et al. (2015). Poly(ADP) ribose polymerase-1 ablation alters eicosanoid and docosanoid signaling and metabolism in a murine model of contact hypersensitivity. Mol. Med. Rep. 11, 2861-2867. doi: 10.3892/mmr. 2014.3044

Lane, K., Derbyshire, E., Li, W., and Brennan, C. (2014). Bioavailability and potential uses of vegetarian sources of omega-3 fatty acids: a review of the literature. Crit. Rev. Food Sci. Nutr. 54, 572-579. doi: 10.1080/10408398.2011.596292

Liu, B., Li, M., Zhou, Z., Guan, X., and Xiang, Y. (2020). Can we use interleukin-6 (IL-6) blockade for coronavirus disease 2019 (COVID19)-induced cytokine release syndrome (CRS)? J. Autoimmun.111:102452. doi: 10.1016/j.jaut.2020.102452

Maskrey, B. H., Megson, I. L., Rossi, A. G., and Whitfield, P. D. (2013). Emerging importance of omega-3 fatty acids in the innate immune response: molecular mechanisms and lipidomic strategies for their analysis. Mol. Nutr. Food Res. 57, 1390-1400. doi: 10.1002/mnfr.201200723

Mehta, P., Mcauley, D. F., Brown, M., Sanchez, E., Tattersall, R. S., Manson, J. J., et al. (2020). COVID-19: consider cytokine storm syndromes and immunosuppression. Lancet 395, 1033-1034. doi: 10.1016/S0140-6736(20)30628-0

Messina, G., Polito, R., Monda, V., Cipolloni, L., Di Nunno, N., Di Mizio, G., et al. (2020). Functional role of dietary intervention to improve the outcome of COVID-19: a hypothesis of work. Int. J. Mol. Sci. 21:3104. doi: $10.3390 /$ ijms 21093104

Muldoon, M. F., Laderian, B., Kuan, D. C., Sereika, S. M., Marsland, A. L., and Manuck, S. B. (2016). Fish oil supplementation does not lower C-reactive protein or interleukin-6 levels in healthy adults. J. Intern. Med. 279, 98-109. doi: $10.1111 /$ joim. 12442

Muscogiuri, G., Barrea, L., Savastano, S., and Colao, A. (2020). Nutritional recommendations for CoVID-19 quarantine. Eur. J. Clin. Nutr. 74, 850-851. doi: 10.1038/s41430-020-0635-2

Ramon, S., Gao, F., Serhan, C. N., and Phipps, R. P. (2012). Specialized proresolving mediators enhance human $\mathrm{B}$ cell differentiation to antibodysecreting cells. J. Immunol. 189, 1036-1042. doi: 10.4049/jimmunol.11 03483

Rangel-Huerta, O. D., Aguilera, C. M., Mesa, M. D., and Gil, A. (2012). Omega3 long-chain polyunsaturated fatty acids supplementation on inflammatory biomakers: a systematic review of randomised clinical trials. Br. J. Nutr. 107(Suppl. 2), S159-S170. doi: 10.1017/S0007114512001559

Saedisomeolia, A., Wood, L. G., Garg, M. L., Gibson, P. G., and Wark, P. A. (2009). Anti-inflammatory effects of long-chain n-3 PUFA in rhinovirus-infected cultured airway epithelial cells. Br. J. Nutr. 101, 533-540. doi: $10.1017 / S 0007114508025798$

Serini, S., and Calviello, G. (2018). Long-chain omega-3 fatty acids and cancer: any cause for concern? Curr. Opin. Clin. Nutr. Metab. Care 21, 83-89. doi: 10.1097/MCO.0000000000000439

Tan, A., Sullenbarger, B., Prakash, R., and Mcdaniel, J. C. (2018). Supplementation with eicosapentaenoic acid and docosahexaenoic acid reduces high levels of circulating proinflammatory cytokines in aging adults: a randomized, controlled study. Prostaglandins Leukot. Essent. Fatty Acids 132, 23-29. doi: $10.1016 /$ j.plefa.2018.03.010

Tao, L. (2015). Oxidation of polyunsaturated fatty acids and its impact on food quality and human health. Adv. Food Technol. Nutr. Sci. 1, 135-137. doi: 10.17140/AFTNSOJ-1-123

Tisoncik, J. R., Korth, M. J., Simmons, C. P., Farrar, J., Martin, T. R., and Katze, M. G. (2012). Into the eye of the cytokine storm. Microbiol. Mol. Biol. Rev. 76, 16-32. doi: 10.1128/MMBR.05015-11

Usdhhs N. I. O. H. and Office of Dietary Supplements (2019). Omega-3 Fatty Acids Fact Sheet for Health Professionals [Online]. US. Department of Health \& Human Services, National Institutes of Health Office of Dietary Supplements: Office of Dietary Supplements (ODS) Available online at: https://ods.od.nih.gov/factsheets/Omega3FattyAcids-HealthProfessional/? fbclid=IwAR3NkUQvHD0vrabGnuegLuCJ1GGWFNtv21Kv8QYLguUwKe_ 4GwPpsUTJKAU (accessed June 1, 2020).

Vedin, I., Cederholm, T., Freund Levi, Y., Basun, H., Garlind, A., Faxen Irving, G., et al. (2008). Effects of docosahexaenoic acid-rich n-3 fatty acid supplementation on cytokine release from blood mononuclear leukocytes: the OmegAD study. Am. J. Clin. Nutr. 87, 1616-1622. doi: 10.1093/ajcn/87. 6.1616 
Yanai, H., Masui, Y., Katsuyama, H., Adachi, H., Kawaguchi, A., Hakoshima, M., et al. (2018). An improvement of cardiovascular risk factors by Omega-3 polyunsaturated fatty acids. J. Clin. Med. Res. 10, 281-289. doi: 10.14740/jocmr3362w

Zhou, Q., Zhang, Z., Wang, P., Zhang, B., Chen, C., Zhang, C., et al. (2019). $\mathrm{EPA}+\mathrm{DHA}$, but not ALA, improved lipids and inflammation status in hypercholesterolemic adults: a randomized, double-blind, placebo-controlled trial. Mol. Nutr. Food Res. 63, e1801157. doi: 10.1002/mnfr.201801157

Zivkovic, A. M., Telis, N., German, J. B., and Hammock, B. D. (2011). Dietary omega-3 fatty acids aid in the modulation of inflammation and metabolic health. Calif. Agric. 65, 106-111. doi: 10.3733/ca.v065n03p106
Conflict of Interest: The authors declare that the research was conducted in the absence of any commercial or financial relationships that could be construed as a potential conflict of interest.

Copyright (C) 2020 Szabó, Marosvölgyi, Szabó, Bai, Figler and Verzár. This is an open-access article distributed under the terms of the Creative Commons Attribution License (CC BY). The use, distribution or reproduction in other forums is permitted, provided the original author(s) and the copyright owner(s) are credited and that the original publication in this journal is cited, in accordance with accepted academic practice. No use, distribution or reproduction is permitted which does not comply with these terms. 